\title{
Transformational Leader Self-Perception And Objective Sales Performance: The Potential Moderating Effects Of Beha- vioral Coping Ability
}

John H. Humphreys, (E-mail: john.humphreys@enmu.edu), Eastern New Mexico University Molly C. Zettel, (E-mail: molly.zettel@enmu.edu), Eastern New Mexico University

\begin{abstract}
This research reports results from an exploratory study that examined the relationship between salespersons' self-perceived leadership styles, behavioral and emotional coping abilities, and objective sales performance. The direct sales staff of a financial services firm provided the data for the study. The self-rater version of the Multifactor Leadership Questionnaire (MLQ 5X, short form) was used to capture the sales personnel's self-perceptions of their leadership styles with respect to transformational and transactional leadership. Two main scales from the Constructive Thinking Inventory (CTI) were used to assess the behavioral and emotional coping abilities of the participants. Data analyses indicated a significant relationship between active transactional leader self-perception, transformational leader self-perception, behavioral coping ability, and sales performance. This was not the case for passive transactional leadership or emotional coping ability. In addition, behavioral coping ability moderated the relationship between transformational self-perception and sales performance such that those sales personnel who perceived themselves as transformational delivered enhanced performance when behavioral coping ability was good rather than poor.
\end{abstract}

\section{Introduction}

乌 n today's competitive marketplace, sales organizations must continually strive to improve the performance of their current sales staffs while attempting to predict the future success of potential sales personnel. In a relatively recent conceptual article, Bass (1997) proposed that the factors more typically associated with transformational leadership might also be considered as effective behaviors for enhancing sales performance. Empirical testing of this proposition, however, is extremely limited. In addition, research has indicated that various personality structures do influence behaviors that are deemed to be transformational (Church \& Waclawski, 1998; Humphreys, 1997; Judge \& Bono, 2000; Sosik \& Megerian, 1999) and many theorists accept the notion that these fundamental personality components are stable (Epstein \& Meier, 1989; Kuhnert \& Lewis, 1987; Roush \& Atwater, 1992) and appropriate for examination in conjunction with many behaviors associated with effective leadership (Hooijberg \& Choi, 2000). In particular, emotional and behavioral coping have been shown to be both associated with transformational leadership (Atwater \& Yammarino, 1993; Humphreys, Einstein, \& Sawyer, 2001) and potentially useful predictors of performance (Atwater, 1992). This article presents findings from an exploratory study to determine the efficacy of incorporating the behaviors associated with transformational leadership and coping ability into a predictive instrument to assess potential sales productivity.

Readers with comments or questions are encouraged to contact the authors via email.

\section{Background}


Burns (1978) is credited with introducing the theoretical construct of transforming leadership. Bass (1985), however, further refined and expanded the work of Burns into a viable model that envisions a behavioral continuum from very avoidant behavior at one end to transformational behaviors at the other (Avolio, Bass, \& Jung, 1995).

\section{Laissez-Faire Leadership}

Laissez-faire behavior is the complete avoidance of leading. Bass (1985) included the avoidance of leadership so the transformational leadership model would include the "full range" of leader behavior (Avolio \& Bass, 1991).

\section{Transactional Leadership}

Transactional leadership is personified by an exchange relationship between the leader and follower. For example, leaders give followers something they want (i.e., pay raise) in exchange for something the leader wants (i.e., follow the rules). They are mutually dependent upon one another and the contributions of each side are understood and rewarded (Burns, 1978).

Transactional leader behavior is characterized by the factors of contingent reward and management-byexception (Bass, 1985). A more active transactional leader typically employs a style of contingent reward (reward is contingent upon the follower meeting an agreed upon, and mutually understood, goal) whereas a more passive transactional leader tends to avoid corrective actions (managing-by-exception) as long as goals are met.

\section{Transformational Leadership}

Transformational leader behavior does not depend upon an exchange of commodities between leader and follower (Bass, 1985). Transformational leaders operate out of deeply held personal value systems that cannot be negotiated or exchanged between individuals. By expressing these personal standards, transformational leaders unite their followers and even alter their followers' goals and beliefs. Transformational leaders achieve this by exhibiting the behaviors of: 1) individual consideration, 2) intellectual stimulation, 3) inspirational motivation, and 4) charisma.

Transformational leaders tend to pay close attention to the individual differences among their followers. They often act as mentors. A primary component of individual consideration is the understanding that each follower has different needs and that those needs would change over time. Therefore, transformational leaders must accurately diagnose the needs of individual followers in order to optimize each follower's individual potential (Avolio, Waldman, \& Yammarino, 1991).

Transformational leaders also provide ways and reasons for followers to alter their perceptions of problems and even their own attitudes and values (Avolio, Waldman, \& Yammarino, 1991). This is characterized by promoting intelligence, rationality, logical thinking, and careful problem solving. An intellectually stimulating leader is intent on showing subordinates new ways of looking at old problems (Avolio, Waldman, \& Einstein, 1988). They tend to emphasize sensible solutions.

Transformational leaders inspire their followers to accomplish great feats. This dimension of transformational leadership is characterized by the communication of high expectations, using symbols to focus efforts, and expressing important purposes in simple ways. Such behavior increases the leader's appeal as it increases the confidence and esteem of followers. Inspirational leaders often provide encouragement and set the standard as far as work ethic is concerned.

Attaining charisma in the eyes of followers is a critical step in becoming a transformational leader (Bass, 1990). Charismatic leaders exert an enormous amount of influence (Conger \& Kanungo, 1988; Howell \& Frost, 1989). Followers place extreme confidence and trust in charismatic leaders (Howell \& Avolio, 1992). This charis- 
matic dimension of transformational leadership is characterized by providing vision and a sense of mission, instilling pride in and among the group, and gaining respect and trust.

More recent iterations of Bass' conceptualization of transformational leadership have divided this charismatic dimension into behavioral and attributed idealized influence. Idealized influence can be considered a culmination of the other three I's (individual consideration, intellectual stimulation, and inspirational motivation) coupled with a strong emotional bond with the leader (Avolio, Waldman, \& Yammarino, 1991). Leaders who demonstrate idealized influence develop much personal power and influence with followers and are, therefore, often labeled as charismatic.

There is a preponderance of literature indicating that transformational leadership can lead to considerable organizational rewards (Bass, 1990; Yammarino, Spangler, \& Bass, 1993) and that transformational leader behavior delivers an augmentation effect, that is, performance that rises above that derived by contingent reward leader behavior alone (Geyer \& Steyrer, 1998; Waldman, Bass, \& Yammarino, 1990; Yammarino, Spangler, \& Bass, 1993). Transformational leadership has been empirically related to perceptions of leader effectiveness, leader and follower satisfaction, follower efforts, and overall organizational performance (Avolio, Waldman, \& Einstein, 1988; Howell \& Avolio, 1993; Humphreys, 2000; Lowe, Kroeck, \& Sivasubramaniam, 1996; Masi, 2000; Waldman, Bass, \& Einstein, 1987). In addition, findings have been reported that suggest transformational leader behavior is associated with employee commitment to the organization, trust in the leader, and positive organizational citizenship behaviors (Bycio, Hackett, \& Allen, 1995; Podsakoff, MacKenzie, Moorman, \& Fetter, 1990).

\section{Transformational Salesperson Behavior}

There is little doubt that successful personal selling and effective leadership both involve the art of influence (Bass, 1997). Just as with effective leaders, successful sales performance is dependent upon perceptions of escalating trust in the salesperson (Hawes, Mast, \& Swan, 1989). Bass (1997) suggests that the transformational leader behaviors might enhance the effectiveness of selling by the following manifestations:

1. Charismatic salespeople: would likely build a buyer's trust, consistently articulate a buyer's needs, and provide effective solutions to meet those needs.

2. Individually Considerate salespeople: would likely share important marketing information with buyers and coach them to help themselves.

3. Inspirationally Motivating salespeople: would likely provide persuasive appeals to buyers using powerful words and symbols.

4. Intellectually Stimulating salespeople: would likely use product knowledge to get buyers to reexamine their assumptions and accept new solutions to meet their needs.

To complete the full range of leader behavior, and the parallel with personal selling, Bass (1997) also proposes that transactional and laissez-faire salesperson behavior should be considered:

5. Contingent Reward salespeople: would likely negotiate deals with buyers for mutual benefit.

6. Managing-by-Exception salespeople: would likely correct buyers' mistakes in selecting and using products and services and fail to properly handle complaints.

7. Laissez-Faire salespeople: would likely demonstrate a lack of concern by delaying or avoiding buyer interaction.

Bass' (1997) speculation does enjoy partial support. Garcia (1995) has reported results that indicate salesperson performance was predicted by "charismatic, inspirational, intellectually-stimulating, and individually considerate behavior" (Bass, 1997, p. 26). Garcia (1995), however, failed to collect data pertaining to transactional or laissez-faire behavior. A more complete examination of the full range of leader behavior and effective selling could prove useful in salesperson selection (Bass, 1997).

\section{Transformational Leader Behavior and Personality Characteristics}


The personal characteristics of transformational leaders have also been the topic of research (Dubinsky, Yammarino, \& Jolson, 1995; Ross \& Offerman, 1997). Bass (1985) believes that this is appropriate as transformational leaders enhance their power by exhibiting important personal traits. Findings have been reported suggesting that locus of control (Howell \& Avolio, 1993), certain dimensions of psychological type (Humphreys, 1997; Roush \& Atwater, 1992), and gender (Maher, 1997) may exhibit a relationship to the factors associated with transformational leadership.

Moreover, research has begun to focus on various personality mechanisms that induce leaders to engage in one level of leader behavior versus another (Avolio, 1994; Kegan, 1992). Theories concerning the development of transformational leader behavior have been offered (Kegan, 1982; Wofford \& Goodwin, 1994; Wofford, Goodwin, \& Whittington, 1998). The attempt to interpret leader behavior emergence has primarily dealt with the manner in which individual leaders build their personal structures of reality. Much of this research suggests an important relationship between the development and exhibition of specific behaviors and an experiential conceptual system (Avolio, 1994; Popper, Mayseless, \& Castelnovo, 2000; Zacharatos, Barling, \& Kelloway, 2000). This experiential system is an integral component of a personality theory known as Cognitive-Experiential Self-Theory.

\section{Cognitive-Experiential Self-Theory}

Cognitive-Experiential Self-Theory (CEST) suggests that there are four basic needs (Epstein, 1990): 1) to maximize pleasure and minimize pain over the foreseeable future; 2) to maintain the model of reality; 3) to maintain relatedness to others; and 4) to enhance self-esteem. CEST explains behavior as the compromise between these motives. In order to assess the status of these four motives, CEST further suggests that there are four basic assumptions that are made to determine to what degree each function is fulfilled (Epstein, 1990). Each individual, within his or her personal theory of reality, has an intuitive interpretation to the degree to which: 1) the world is benign, that is, a source of pleasure versus misery, 2) the world is meaningful (predictable, controllable, and just versus chaotic and uncontrollable), 3) people are considered to be worth relating to (a source of support and affection versus threat and hostility), and 4) the self is perceived as worthy (competent, moral, and lovable versus incompetent, bad, and unlovable).

CEST suggests that there are three conceptual systems: 1) a rational conceptual system that operates at the conscious level, 2) an experiential conceptual system that operates at the preconscious level, and 3) an associationistic conceptual system that operates primarily at the unconscious level. CEST accords the central role to the preconscious level as the experiential system automatically interprets reality and directs behavior in everyday life (Epstein, 1990). Epstein (1990) suggests that people falsely assume that their behavior is primarily directed by reason. He attributes this belief to our conscious awareness and ability to rationalize. CEST assumes that all behavior is the product of the joint input of the experiential and rational systems. The experiential system automatically operates rapidly and efficiently and supports immediate action from a holistic view. In contrast, the rational system is analytical, deliberative, and effortful, operating primarily through language. Their relative importance is primarily determined by emotional and situational variables (Epstein, 1998). For example, solving a mathematical equation would likely trigger the rational system, whereas, interpersonal events, such as the salesperson/buyer relationship, would engage the experiential system. The experiential system's fundamental role in determining behavior has led to the construct of constructive thinking.

\section{Constructive Thinking Ability}

Epstein (1991) describes the logic behind constructive thinking ability as follows:

"If emotions and, to a large extent, behavior, are determined automatically by the functioning of the experiential conceptual system, as CEST maintains, then the effectiveness with which the experiential system operates should play an important role in determining a person's success in everyday living. This raises an interesting question. Is it possible that one could obtain a measure of the overall effectiveness of the experiential system in a manner analogous to the use of intelligence tests to measure the effectiveness of the rational system? If so, what is it that would 
have to be measured? The answer is that one would have to sample a person's typical automatic thinking" (Epstein, 1991, p. 101).

Epstein (1990) suggests that there are two dimensions of automatic thinking: content and process. Content refers to specific components of an individual's personal theory of reality (i.e., people are either generally trustworthy or not). Process refers to how the system actually operates. Epstein (1991) illustrates these two variables with the following examples. The statement, "When I fail a test, I feel that I'm a total failure and that I will never amount to anything," is a poor response to both content and process. The content is overly pessimistic and the process is one of gross overgeneralization. When the response is more like, "When I do well on a test, I feel I'm a success and that I will succeed in any endeavor," the content is positive but the process is again an extreme overgeneralization. A constructive response for both dimensions could be, "When I fail a test, I realize it's only one test, and I learn from the experience without getting upset." This statement demonstrates positive content and process. In reality though, even very intelligent people often think destructively and recognize that they do so, but have great difficulty in changing their thinking patterns. Thus, intellective intelligence and constructive thinking are separate constructs (Epstein, 1991). Since the intelligence of the experiential system determines an individual's place along the constructive thinking continuum, constructive thinking is often referred to as practical intelligence (Atwater, 1992).

\section{Behavioral and Emotional Coping Ability}

Although constructive thinking, as a construct, encompasses both constructive and destructive thinking styles, the constructive thinking patterns of behavioral and emotional coping have received the most attention. Behavioral coping ability refers to the predisposition to think in an action-oriented fashion and approach problems with great energy. These are people that do not procrastinate; indeed they are too busy developing a plan for action. Emotional coping refers to the ability to not take things personally. These are people who are not overly sensitive and do not overreact when problems arise nor concern themselves with things over which they have no control (Atwater, 1992).

Several studies have shown significant relationships between coping ability and physical and mental health (Hoyer, Averbeck, Heidenreich, Stangier, Pohlmann, \& Rossler, 1998; Park, Moore, Turner, \& Adler, 1997; Scheuer \& Epstein, 1997) and success in social relations and the workplace (Epstein, 1991; Katz \& Epstein, 1991; Epstein \& Meier, 1989). In a study of school administrators, those with high practical intellect were more likely to handle larger workloads (Green, 1988). Although more productive, these administrators reported less stress and greater job satisfaction than did their counterparts with lesser coping capabilities (Epstein, 1990). Further, in a study examining the sales manager/sales follower relationship, salespeople who worked for managers that exhibited good coping skills were more satisfied with their positions and willing to exert greater effort (Humphreys \& Einstein, 2001).

In addition, behavioral and emotional coping abilities have been empirically linked with leadership in general (Williams, 2000) and, more particularly, with the transformational leader behaviors (Atwater \& Yammarino, 1993). Leader coping ability has also been shown to moderate the relationship between transformational leader behavior and support for innovation (Humphreys, in press). Further, Atwater (1992), in an examination of aspiring naval officers, has demonstrated that behavioral and emotional coping abilities are potentially effective measures for predicting job performance. She suggests that "more work needs to be done to assess the relationships between behavioral and emotional coping and various performance measures in other organizational contexts" (Atwater, 1992, p. 41).

\section{Purpose}

Therefore, the purpose of the study was threefold. First, we wanted to empirically assess Bass' (1997) assertion that the transformational leadership paradigm might also prove effective for enhancing and predicting sales performance. Second, our aim was to evaluate Atwater's (1992) contention that coping ability might serve as a useful predictor of performance in a selling context. Third, we wanted to determine if coping ability might moderate the relationship between transformational leader perception and objective sales performance. These proposed relationships are represented graphically in Figure 1. It was our hope that the answers to these exploratory questions might 
assist in the construction of an efficient and useful instrument designed to predict salesperson effectiveness.

\section{Summary and Hypotheses}

Based upon Bass' (1997) conceptualization of transformational leader behavior and effective selling, the authors postulated that the behaviors associated with transformational leadership and contingent reward would exhibit a significant relationship with salesperson performance. Such a relationship was not expected with the passive transactional and laissez-faire leader behaviors. In addition, we anticipated that behavioral and emotional coping would exhibit a positive relationship with perceived transformational leadership and sales performance. Finally, the expectation was that coping ability would influence the relationship between transformational leadership and sales performance such that those salespeople who viewed themselves as transformational would demonstrate greater sales performance when coping ability was good rather than poor. To investigate these expectations, the following hypotheses were examined:

\section{Figure 1}

Proposed Relationships Between Perceived Leadership Style, Coping Ability, and Sales Performance

Maximum

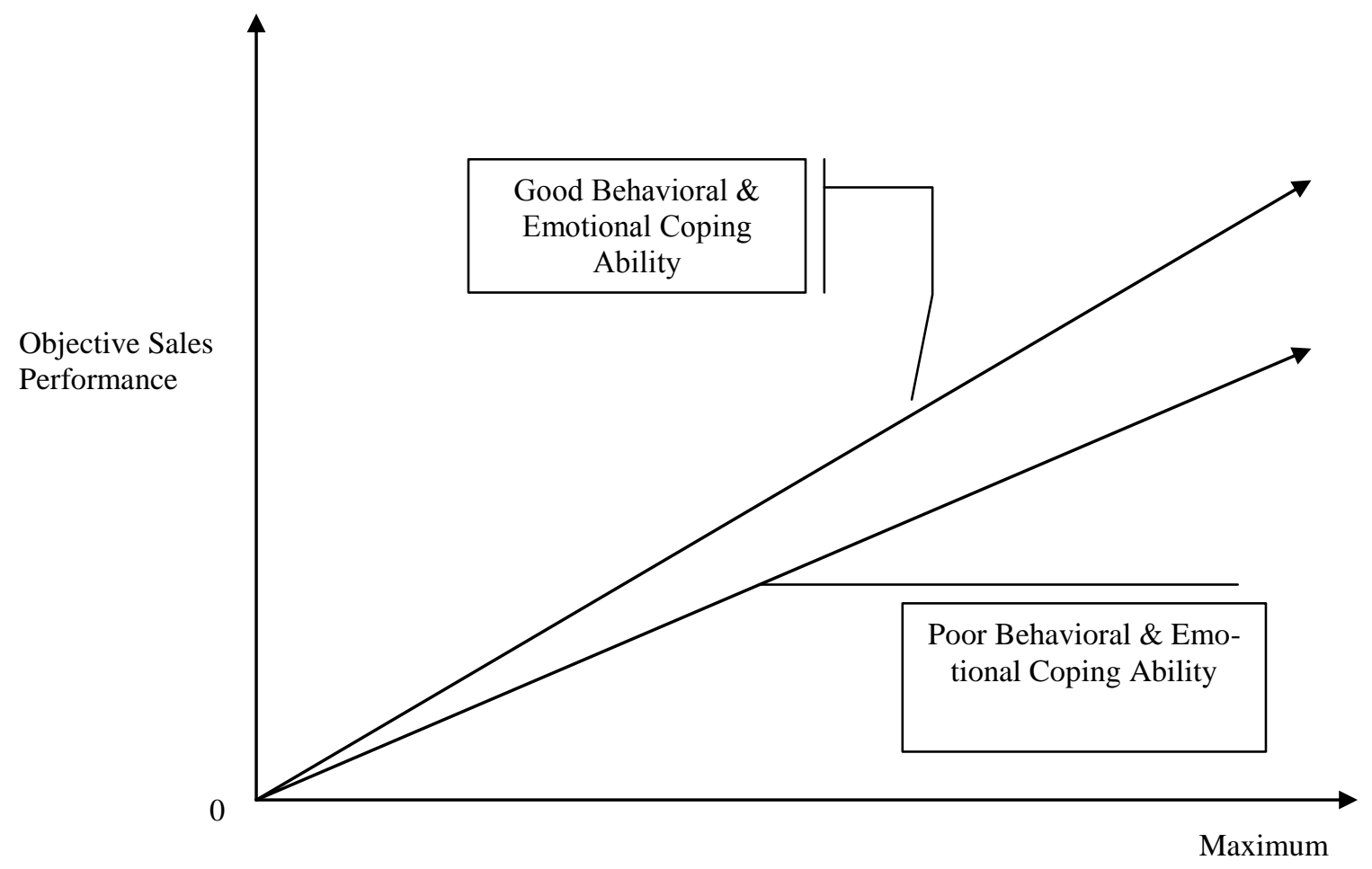

Salesperson Perceived Transformational Leadership Behaviors

H 1: Transformational leader self-perception will exhibit a positive relationship with objective sales performance.

H 2: Active transactional (contingent reward) leader self-perception will exhibit a positive relationship with 
objective sales performance.

H 3: Passive transactional (management-by-exception) leader self-perception will not exhibit a positive relationship with objective sales performance.

H 4: Laissez-faire leader self-perception will exhibit a negative relationship with objective sales performance.

H 5: Salespeople who possess good emotional coping ability will exhibit a positive relationship with objective sales performance.

H 6: Salespeople who possess good behavioral coping ability will exhibit a positive relationship with objective sales performance.

H 7: Salespeople who perceive themselves as transformational leaders will exhibit greater objective sales performance than those that do not perceive themselves as transformational leaders.

H 8: Salesperson emotional coping ability will moderate the relationship between transformational leader perception and sales performance such that those salespeople that perceive themselves as transformational leaders will exhibit greater objective sales performance when emotional coping ability is good rather than poor.

H 9: Salesperson behavioral coping ability will moderate the relationship between transformational leader perception and sales performance such that those salespeople that perceive themselves as transformational leaders will exhibit greater objective sales performance when behavioral coping ability is good rather than poor.

\section{Method}

\section{Sample}

The subjects were direct sales representatives employed by one division of a financial services firm. The host organization operates several lending divisions within the continental United States. Based upon self-reporting demographics, 29 percent of the respondents were in the $21-30$ age group, 12.5 percent were in the $31-40$ age group, 46 percent were in the $41-50$ age group, and 12.5 percent identified themselves as being in the 51 and over age bracket. Also, 37.5 percent reported their tenure with the organization as less than 5 years, 12.5 percent from 6 10 years, and 50 percent as having served for 10 years or longer. The sample was 63 percent male and 37 percent female.

\section{Instruments and Measures}

Transformational, Transactional, and Laissez-faire Leader Behavior. Perceived leader behaviors were measured by using the self-rater version of Bass and Avolio's (1995) Multifactor Leadership Questionnaire (MLQ 5X - short form). The MLQ $5 \mathrm{X}$ short form is a 45-question instrument, in Likert-like format, that identifies the factors associated with transformational, transactional, and laissez-faire leadership. The respondents were asked to indicate the frequency of behaviors they would exhibit if placed in a leadership role on a scale ranging from $0=$ not at all to $4=$ frequently, if not always.

For each leadership scale, the corresponding items were summed and divided by the number of items to form a scale range from 0.0 to 4.0 (Avolio, Waldman, \& Einstein, 1988). These options have a magnitude estimation based ratio to each other of 4:3:2:1:0 (Bass, Cascio, \& O'Connor, 1974).

The transformational leadership scale titles, typical items, and internal reliabilities are as follows:

1. Idealized Influence (Attributed) - "I would instill pride in being associated with me" (4 items. Internal reliability coefficient of 0.71 )

2. Idealized Influence (Behavior) - "I would talk about my most important values and beliefs" (4 items. Internal reliability coefficient of 0.78 )

3. Inspirational Motivation - "I would talk optimistically about the future" (4 items. Internal reliability coefficient of 0.84 ) 
4. Intellectual Stimulation - "I would seek differing perspectives when solving problems" (4 items. Internal reliability coefficient of 0.89 )

5. Individualized Consideration - "I would treat each follower as an individual with different needs, abilities, and aspirations" (4 items. Internal reliability coefficient of 0.86 )

The transactional leadership scale titles, typical items, and internal reliabilities are as follows:

6. Contingent Rewards - "I would make sure that followers received appropriate rewards for achieving performance targets" (4 items. Internal reliability coefficient of 0.62 )

7. Management-by-exception (Active) - "I would focus attention on irregularities, mistakes, exceptions, and deviations from standards" (4 items. Internal reliability coefficient of 0.84 )

8. Management-by-exception (Passive) - "I would fail to intervene until problems become serious" (4 items. Internal reliability coefficient of 0.74 )

To complete the continuum of leader behavior, the Multifactor Leadership Questionnaire (MLQ) also identifies nonleadership:

9. Laissez-Faire - "I would sometimes be absent when needed" (4 items. Internal reliability coefficient of $0.66)$

These nine leadership behaviors (idealized influence [attributed], idealized influence [behavioral], inspirational motivation, individualized consideration, intellectual stimulation, contingent rewards, management-byexception [active], management-by-exception [passive], and laissez-faire), are what Avolio and Bass (1991) refer to as the "full range" of leader behavior and served as the independent variable(s) in the study.

Behavioral and Emotional Coping Ability. Salesperson behavioral and emotional coping ability was established by using the main constructive thinking scales from Epstein's (1993) Constructive Thinking Inventory (CTI). The Constructive Thinking Inventory (CTI) is a 108-item self-report that measures automatic constructive and destructive thinking. The CTI provides a measure of an individual's tendency to automatically think in ways that are important for problem solving with minimal stress. Respondents rate these items on a 5-point scale to indicate the degree to which they believe them to be true or false (Epstein, 1993).

The coping scale titles, typical items, and internal reliabilities are as follows:

1. Behavioral Coping Ability - "I am the kind of person who takes action rather than just thinks or complains about a situation." (14 items. Internal reliability coefficient of 0.87 )

2. Emotional Coping Ability - "When unpleasant things happen to me, I don't let them prey on my mind" (25 items. Internal reliability coefficient of 0.95 )

Salesperson coping ability was examined both as an independent variable and as a potential moderating variable between transformational leadership and objective sales performance.

Objective Sales Performance. One performance measure was employed in this investigation. For the purpose of the current study, objective sales performance was operationally defined as the average dollar amount of new loan volume generated per full time staff during the previous calendar year. This performance measure served as the dependent variable.

\section{Procedure}

The data used for this investigation were collected during the second quarter of 2001. A letter from the researchers, briefly describing the study and asking for participation, was mailed (USPS) to each sales unit within the host division. All sales personnel were asked to participate in the study. A packet containing three (3) Constructive Thinking Inventories (CTI) and three (3) copies of the Multifactor Leadership Questionnaire (MLQ), along with a 
cover letter, was sent to each participating sales office (no sales office had more than three sales personnel). The cover letter gave a brief description of the study and the questionnaires. The salespeople were instructed to complete the CTI, in private, and return to the researcher by mail (USPS). Further, these sales personnel were instructed to imagine that they were suddenly thrust into a leadership position. Each salesperson was supplied a copy of the selfrating version of the MLQ. They were asked to rate what they believe would be their leader behavior by completing the MLQs, individually and anonymously, and returning them to the researchers. Self-addressed, postage paid envelopes were provided to all participants. A second letter was mailed to all branch offices, approximately one week after the initial call, to further encourage participation.

Of the seventy-one (71) salespeople surveyed, twenty-five (25) returned completed instruments but one (1) was missing needed data. Thus, the number of sales personnel participating was reduced to twenty-four $(n=24)$. Performance data were self-reported as a part of the sample demographics.

\section{Analysis of the Data}

The Multifactor Leadership Questionnaires were hand scored by the researchers. This established the leadership ratings for each salesperson as to the transformational, transactional, and laissez-faire leader behaviors perceived. For the purpose of the current study, the transformational leader behaviors were also subsumed into one underlying construct of transformational leadership. Prior research has demonstrated that the transformational behaviors are intercorrelated and may be combined as an appropriate variable for statistical purposes (Avolio \& Bass, 1999; Carless, 1998; Dubinsky, Yammarino, Jolson, \& Spangler, 1995). Those salespeople with transformational scores above the mean were considered transformational leaders. Those below it were labeled as more transactional in nature. The transformational and transactional leader sub-groups did not overlap.

The Constructive Thinking Inventory (CTI) answer sheets were also hand scored by the researchers. In addition to raw scores, responses that corresponded to the behavioral coping and emotional coping scales were summed for the purpose of assigning salespeople to good coping and poor coping subgroups. Those sales personnel with coping scores greater than the mean were considered to have good coping ability. Likewise, those with scores falling at or below the mean were labeled as exhibiting poorer behavioral and emotional coping skills. These subsamples did not overlap.

Pearson product moment correlation was used to test hypotheses one through six. Hypotheses seven, eight, and nine were examined by performing independent samples T tests. Further, regression analysis was employed to determine which of the independent variables might most effectively predict sales performance. All hypotheses were tested at the 0.05 level of significance.

\section{Results}

Descriptive statistics are presented in Table 1 for all measures. The sample produced transformational leader mean scores for idealized influence (attributed), idealized influence (behavior), inspirational motivation, intellectual stimulation, and individual consideration of 3.18,3.03,3.30,2.81, and 3.16, respectively. These mean scores are considerably higher than the composite mean scores of 2.56, 2.64, 2.64, 2.51, and 2.66 presented in the MLQ 5X technical manual (Avolio, Bass, \& Jung, 1995). This would indicate that these salespeople perceive themselves as being more transformational than most leaders based upon follower ratings. 
Table 1

\section{Descriptive Statistics}

\section{Measure}

Idealized Influence (attributed)

Idealized Influence (behavioral)

Inspirational Motivation

Intellectual Stimulation

Individual Consideration

Transformational Leadership *

Contingent Reward

Management-by-Exception (active)

Management-by-Exception (passive)

Laissez-Faire

Behavioral Coping

Emotional Coping

Sales Performance (millions)
Mean

3.18

3.03

3.30

2.81

3.16

15.48

3.40

1.71

1.39

0.55

53.88

84.29

$\$ 6.06$

\section{$\underline{\text { Standard Deviation }}$}

.508

.735

.594

.778

.671

2.889

.483

.952

.850

.547

8.814

18.530

$\$ 3.296$

* Transformational leadership is the combined measure of idealized influence (attributed \& behavioral), inspirational motivation, intellectual stimulation, \& individual consideration.

The sample exhibited mean scores for the transactional leader behaviors of contingent reward, management-by-exception (active), and management-by-exception (passive) of 3.40, 1.71, and 1.39, respectively. Avolio, Bass, and Jung (1995) report corresponding means using the MLQ 5X of 2.20, 1.75, and 1.11. This could suggest that the current salesperson sample believes that they would employ contingent reward behavior to a greater degree than most leaders based upon follower ratings.

The sample displayed a mean score of 0.55 for laissez-faire leader behavior. This compares to a 0.89 mean score reported by the MLQ 5X technical manual (Avolio, Bass, \& Jung, 1995). This might imply that the current salesperson sample believes that they would not exhibit non-leadership as often as most leaders based upon follower ratings.

The behavioral and emotional coping scale scores of the sample exhibited mean scores of 53.88 and 84.29 , respectively. This compares to mean scores of 52.29 and 78.34 reported by the developer of the CTI for an adult population (Epstein, 1987). This would indicate that the sample's ability to think in a constructive manner is roughly equivalent to that of a normal population.

Intercorrelations among the perceived leadership styles, coping abilities, and sales performance are presented in Table 2. As expected, the transformational leader behaviors of idealized influence (attributed and behavior), inspirational motivation, intellectual stimulation, and individual consideration were all positively correlated. Previous research has established that the transformational factors are intercorrelated and can be analyzed as a single transformational leadership construct (Dubinsky, Yammarino, Jolson, \& Spangler, 1995). In doing so, transformational leadership exhibited a significant relationship with the performance variable. Therefore, hypothesis one was accepted. 
Table 2

Correlations Among Perceived Leadership Style, Coping Abilities, and Sales Performance

\begin{tabular}{l|cccccccc} 
& TF & CR & MBEA & MBEP & LF & BC & EC & PERF \\
\hline TF & - & & & & & & & \\
CR & $.779^{* *}$ & - & & & & & \\
MBEA & $-.688^{* *}$ & $-.453^{*}$ & - & & & & \\
MBEP & -.239 & .049 & .340 & - & & & \\
LF & $-.490^{*}$ & -.184 & $.532^{* *}$ & $.499^{*}$ & - & & \\
BC & $.544^{* *}$ & $.638^{* *}$ & $-.470^{*}$ & -.151 & -.321 & - & \\
EC & .390 & .340 & $-.577^{*}$ & -.128 & $-.482^{*}$ & $.738^{* *}$ & - & \\
PERF & $.446^{*}$ & $.519^{* *}$ & -.340 & -.134 & -.176 & $.601 * *$ & .383 & -
\end{tabular}

* Correlation is significant at the 0.05 level

** Correlation is significant at the 0.01 level

$\begin{array}{ll}\text { Note: } & T F \\ C R & =\text { Transformational leadership } \\ M B E A & =\text { Management-by-Exception (active) } \\ M B E P & =\text { Management-by-Exception (passive) } \\ L F & =\text { Laissez-faire } \\ B C & =\text { Behavioral Coping } \\ E C & =\text { Emotional Coping } \\ P E R F & =\text { Sales Performance }\end{array}$

In addition, the active transactional behavior of contingent reward also exhibited a positive correlation with transformational leadership. This too was expected, as contingent reward behavior has previously been shown to be an effective leadership behavior, which is often augmented by transformational leader behavior, and positively correlated with transformational leadership ratings (Avolio, Waldman, \& Einstein, 1988; Howell \& Avolio, 1993; Waldman, Bass, \& Yammarino, 1990). Contingent reward behavior was also positively correlated to sales performance. Therefore, hypothesis two was accepted.

The transactional behavior of active management-by-exception exhibited an expected negative correlation with transformational leadership and contingent reward behavior. There was no significant correlation between active management-by-exception and passive management-by-exception. This finding might provide support for the most recent nine-factor version of the MLQ, which separates management-by-exception behavior into active and passive forms. Although negative, neither of the management-by-exception measures exhibited a significant relationship with the performance variable. Therefore, hypothesis three was accepted.

The non-leadership behavior of laissez-faire exhibited a negative correlation with transformational leadership. Laissez-faire perception, however, was not negatively correlated with contingent reward, as expected, but did share a significant relationship with the passive transactional measures. Presumed laissez-faire behavior did exhibit an expected negative relationship with sales performance. This relationship, however, did not rise to the level of statistical significance. Therefore, hypothesis four was rejected.

Emotional coping ability was highly correlated with behavioral coping but not with transformational or contingent reward leadership. Hypothesis five proposed that salespeople with good emotional coping ability would be positively correlated with sales performance. This relationship, although positive, was not statistically significant. Therefore, hypothesis five was rejected.

Behavioral coping ability, however, was significantly correlated with both transformational and contingent reward leader perceptions. Moreover, behavioral coping ability exhibited a strong relationship ( 0.01 level) with ob- 
jective sales performance. Thus, hypothesis six was accepted.

To further test Bass' (1997) conceptualization of transformational leadership and effective selling behavior, the sample was divided around the mean to determine if there was a significant difference in sales performance between those salespeople that perceived themselves as transformational and those that did not. The subgroup $(n=13)$ that perceived themselves to be transformational leaders exhibited mean sales performance of $\$ 7.57$ million. Those that fell below the mean $(n=11)$ exhibited mean sales performance of $\$ 4.26$ million. An independent samples T test confirmed that this difference in means was statistically significant $(\mathrm{t}=2.893$; sig. $=.009)$. Therefore, hypothesis seven was accepted.

Hypotheses eight and nine sought to determine if emotional and/or behavioral coping ability would moderate the relationship between transformational leader self-perception and sales performance. That is, would those salespeople that perceived themselves to be transformational exhibit greater sales performance if they also demonstrated good coping abilities? Emotional coping ability showed no relationship with performance or transformational leadership and, therefore, was not expected to serve as a moderating variable. Salespeople who considered themselves to be transformational leaders and good emotional copers produced mean sales performance of $\$ 8.06$ million. Those transformational salespeople with poorer emotional coping abilities delivered mean sales performance of $\$ 6.49$ million. An independent samples $\mathrm{T}$ test determined that there was no significant difference between these groups $(\mathrm{t}=.724 ; \mathrm{sig} .=.500)$. Therefore, hypothesis eight was rejected.

Behavioral coping ability, however, did positively correlate to both transformational leadership and objective sales performance. Those salespeople who perceived themselves to be transformational leaders and who also demonstrated good behavioral coping abilities produced mean sales performance of $\$ 8.9$ million. Those selfperceived transformational leaders with poorer behavioral coping skills produced mean sales performance of $\$ 4.59$ million. An independent samples $\mathrm{T}$ test confirmed that there was a significant difference in sales performance between these two groups $(\mathrm{t}=3.856$; sig. $=.004)$. Thus, hypothesis nine was accepted.

In addition, the researchers were interested in determining the potential value of developing a predictive sales instrument based upon Bass' (1997) conceptualization of transformational selling behavior and Atwater's (1992) contention that coping ability might be an effective performance predictor. To begin this process, a backward regression model was created. Based upon the findings of the exploratory study, the transformational leader behaviors, contingent reward behavior, and behavioral coping ability scores were entered into the regression equation. With all variables included, the model accounted for roughly 75 percent of the variance observed in salesperson performance. With the backward regression analysis, variables were excluded (criterion of F-to-remove $>=.100$ ) to determine which combination of perceived behavioral indices would provide the best predictive model. By examining the regression models, and comparing the corresponding t statistics, the measures of behavioral coping, idealized influence (behavioral), intellectual stimulation, and individual consideration appear to construct the most efficient model, accounting for over 73 percent of the variance in predicting salesperson performance. Therefore, it would appear that a reasonable predictive instrument for salespeople might be created using salesperson perceptions of these measures.

\section{Discussion}

Bass (1997) proposed that the transformational leader paradigm might also be beneficial when applied to personal selling behavior. This exploratory study supports Bass' conjecture. Salespersons' self-perceptions of transformational leadership were positively related to sales performance. Clearly, those salespeople that viewed themselves as transformational were more productive than those that did not.

In addition, this investigation adds to the growing body of literature suggesting that coping ability, in this case behavioral coping ability, may be a potential predictor of performance. The insignificant relationship between emotional coping ability and sales performance was surprising. Intuitively, one can easily make the connection between a thinking style of high self-acceptance and effective performance. Along with this self-acceptance, however, a salesperson with good emotional coping ability might also be insensitive to customers and peers and appear to 
have a "less than caring" attitude. This is certainly an area for future study.

Further, the finding that behavioral coping ability influenced the relationship between transformational leader self-perception and objective sales performance could be significant. It appears that behavioral coping ability might serve as a moderating variable that could add to the predictive capability of transformational selling. Based upon the findings of this exploratory study, it is our intention to begin testing the reliability and validity of such a predictive instrument.

Caution, however, as to the current findings. This was an exploratory study, that is, more or less of a fishing expedition to determine if a more rigorous examination might be warranted. Clearly, a larger sample size is needed before definitive inferences can be made. Also, this study was conducted within one company in a single industry. Future examinations should include salespeople from various organizations and selling contexts. Further, the salespeople who participated in the current study already had experience in the sales role and environment. To truly determine the efficacy of the predictive instrument described, a longitudinal study of sales position applicants and newly hired salespeople should be undertaken.

\section{References}

1. Atwater, L.E. (1992). Beyond cognitive ability: Improving the prediction of performance. Journal of Business and Psychology, 7(1), 27-44.

2. Atwater, L.E., \& Yammarino, F.J. (1993). Personal attributes as predictors of superiors' and subordinates' perceptions of military academy leadership. Human Relations, 46(5), 645-661.

3. Avolio, B.J. (1994). The "natural": Some antecedents to transformational leadership. International Journal of Public Administration, 17(9), 1559-1581.

4. Avolio, B.J., \& Bass, B.M. (1991). The Full Range Of Leadership Development. Binghamton, NY: Center for Leadership Studies.

5. Avolio, B.J., \& Bass, B.M. (1999). Re-examining the components of transformational and transactional leadership using the Multifactor Leadership Questionnaire. Journal of Occupational and Organizational Psychology, 72(4), 441-463.

6. Avolio, B.J., Bass, B.M., \& Jung, D.I. (1995). Multifactor Leadership Questionnaire Technical Report. Redwood City, CA: Mind Garden.

7. Avolio, B.J., Waldman, D.A., \& Einstein, W.O. (1988). Transformational leadership in a management game simulation. Group and Organization Studies, 13(1), 59-80.

8. Avolio, B. J., Waldman, D. A., \& Yammarino, F. J. (1991). The four I's of transformational leadership. Journal of European Industrial Training, 15(4), 9-16.

9. Bass, B.M. (1985). Leadership and performance beyond expectations. New York: Free Press.

10. Bass, B.M. (1990). From transactional to transformational leadership: Learning to share the vision. Organizational Dynamics, 18(3), 19-31.

11. Bass, B.M. (1997). Personal selling and transactional/transformational leadership. The Journal of Personal Selling and Sales Management, 17(3), 19-28.

12. Bass, B.M., \& Avolio, B.J. (1995). The Multifactor Leadership Questionnaire - 5X short form. Redwood City, CA: Mind Garden.

13. Bass, B.M., Cascio, W.F., \& O'Connor, E.J. (1974). Magnitude estimations of expressions of frequency and amount. Journal of Applied Psychology, 59, 313-320.

14. Burns, J.M. (1978). Leadership. New York: Harper.

15. Bycio, P., Hackett, R.D., \& Allen, J.S. (1995). Further assessment of Bass's (1985) conceptualization of transactional and transformational leadership. Journal of Applied Psychology, 80(4), 468-478.

16. Carless, S.A. (1998). Assessing the discriminant validity of the transformational leader behaviour as measured by the MLQ. Journal of Occupational and Organizational Psychology, 71(4), 353-358.

17. Church, A.H., \& Waclawski, J. (1998). The relationship between individual personality orientation and executive executive leadership behavior. Journal of Occupational and Organizational Psychology, 71(2), 99-125.

18. Conger, J., \& Kanungo, R. (1988). Charismatic leadership: The elusive factor in organizational effectiveness. San Francisco, CA: JosseyBass Publishers. 
19. Dubinsky, A.J., Yammarino, F.J., \& Jolson, M.A. (1995). An examination of linkages between personal

20. characteristics and dimensions of transformational leadership. Journal of Business and Psychology, 9(3), 315335.

21. Dubinsky, A.J., Yammarino, F.J., Jolson, M.A., \& Spangler, W.D. (1995). Transformational leadership: An initial investigation in sales management. Journal of Personal Selling and Sales Management, 15(2), 17-29.

22. Epstein, S. (1990). Cognitive-Experiential Self-Theory. In L.A. Pervin (Ed.), Handbook of personality: Theory and research (pp. 165-192). New York: Guilford Press.

23. Epstein, S. (1991). Cognitive-Experiential Self-Theory: Implications for developmental psychology. In M.R.Gunnar, A.L. Stroufe, \& L. Alan (Eds.), Self-processes and development (pp. 79-123). Hillsdale, NJ: Lawrence Erlbaum Associates, Inc.

24. Epstein, S. (1993). Manual for the Constructive Thinking Inventory. Amherst, MA: University of Massachusetts at Amherst.

25. Epstein, S. (1998). Constructive thinking: The key to emotional intelligence. Westport, Connecticut: Praeger.

26. Epstein, S., \& Meier, P. (1989). Constructive thinking: A broad coping variable with specific components. Journal of Personality and Social Psychology, 57(2), 332-350.

27. Garcia, J.L. (1995). Transformational leadership processes and salesperson performance effectiveness: A theoretical and partial empirical examination. Unpublished dissertation, The Fielding Institute, Santa Barbara, CA.

28. Geyer, A.L.J., \& Steyrer, J.M. (1998). Transformational leadership and objective performance in banks. Applied Psychology: An International Review, 47(3), 397-420.

29. Green, M. (1988). Occupational stress: A study of public school administrators in Southeast Massachusetts. Unpublished doctoral dissertation, University of Massachusetts, Amherst, MA.

30. Hawes, J.M., Mast, K.E., \& Swan, J.E. (1989). Trust earning perceptions of sellers and buyers. Journal of Personal Selling and Sales Management, 9, 1-8.

31. Hooijberg, R., \& Choi, J. (2000). From selling peanuts and beer in Yankee Stadium to creating a theory of transformational leadership: An interview with Bernie Bass. Leadership Quarterly, 11(2), 291-307.

32. Howell, J.M., \& Avolio, B.J. (1992). The ethics of charismatic leadership. Submission or liberation? Academy of Management Executive, 6(2), 43-54.

33. Howell, J.M., \& Avolio, B.J. (1993). Transformational leadership, transactional leadership, locus of control, and support for innovation: Key predictors of consolidated-business-unit performance. Journal of Applied Psychology, 78(6), 891-902.

34. Howell, J.M., \& Frost, P.J. (1989). A laboratory study of charismatic leadership. Organizational Behavior and Human Decision Processes, 43, 243-269.

35. Hoyer, J., Averbeck, M., Heidenreich, T., Stangier, U., Pohlmann, K., \& Rossler, G. (1998). The Constructive Thinking Inventory: Factorial structure in healthy individuals and patients with chronic skin diseases. European Journal of Psychological Assessment, 14(3), 226-233.

36. Humphreys, J.H. (1997). The relationship between transformational leadership and personality type as predictors of organizational performance. In C.G. Thor, J.A. Edosomwan, R. Poupart, \& D.J. Sumanth (Eds.), Productivity and Quality Management Frontiers - VI (pp. 58-68). Norcross, GA: Engineering \& Management Press.

37. Humphreys, J.H. (2000). Transformational, transactional, and laissez-faire leader behavior and constructive thinking ability: The relationship with proximal sales unit performance. Dissertation Abstracts, ISBN 0-59995400-0.

38. Humphreys, J.H. (in press). Transformational and transactional leader behavior: The relationship with support for e-commerce and emerging technology. Journal of Management Research.

39. Humphreys, J.H., \& Einstein, W.O. (2001). Leader constructive thinking ability: The relationship with follower extra effort, satisfaction, effectiveness perceptions, and performance. Proceedings of the $43^{\text {rd }}$ Annual Southwest Academy of Management Meeting (pp. 126-132), New Orleans.

40. Humphreys, J.H, Einstein, W.O., \& Sawyer, T. (2001). Transformational, transactional, and laissez-faire leader behavior and constructive thinking ability: The relationship with consolidated-follower-unit performance. Proceedings of the $8^{\text {th }}$ Annual American Society of Business and Behavioral Sciences Meeting, Las Vegas.

41. Judge, T.A., \& Bono, J.E. (2000). Five-factor model of personality and transformational leadership. Journal of Applied Psychology, 85(5), 751-765.

42. Katz, L., \& Epstein, S. (1991). Constructive thinking and coping with laboratory-induced stress. Journal of Personality and Social Psychology, 61(5), 789-800. 
43. Kegan, R. (1982). The evolving self: Problem or process in human development. Cambridge, MA: Harvard University Press.

44. Kuhnert, K.W., \& Lewis, P. (1987). Transactional and transformational leadership: A constructive/developmental analysis. Academy of Management Review, 12(4), 648-657.

45. Lowe, K.B., Kroeck, K.G., \& Sivasubramaniam, N. (1996). Effectiveness correlates of transformational and transactional leadership: A meta-analytic review of the MLQ literature. Leadership Quarterly, 7, 385-425.

46. Maher, K.J. (1997). Gender-related stereotypes of transformational and transactional leadership. Sex Roles, 37(3), 209-225.

47. Masi, R.J. (2000). Effects of transformational leadership on subordinate motivation, empowering norms, and organizational productivity. International Journal of Organizational Analysis, 8(1), 16-48.

48. Park, C.L., Moore, P.J., Turner, R.A., \& Adler, N.E. (1997). The roles of constructive thinking and optimism in psychological and behavioral adjustment during pregnancy. Journal of Personality and Social Psychology, 73(3), 584-592.

49. Podsakoff, P.M., MacKenzie, S.B., Moorman, R.H., \& Fetter, R. (1990). Transformational leader behaviors and their effect on followers' trust in leader, satisfaction, and organizational citizenship behaviors. Leadership Quarterly, 1(2), 107-142.

50. Popper, M., Mayseless, O., \& Castelnovo, O. (2000). Transformational leadership and attachment. Leadership Quarterly, 11(2), 267-291.

51. Ross, S.M., \& Offerman, L.R. (1997). Transformational leaders: Measurement of personality attributes and work group performance. Personality and Social Science Bulletin, 23(10), 1078-1086.

52. Roush, P.E., \& Atwater, L.E. (1992). Using the MBTI to understand transformational leadership and selfperception accuracy. Military Psychology, 4(1), 17-34.

53. Scheurer, E., \& Epstein, S. (1997). Constructive thinking, reactions to a laboratory stressor, and symptoms in everyday life. Anxiety, Stress, and Coping, 10, 269-303.

54. Sosik, J.J., \& Megerian, L.E. (1999). Understanding leader emotional intelligence and performance: The role of self-other agreement on transformational leadership perceptions. Group and Organization Management, 24(3), 367-390.

55. Waldman, D.A., Bass, B.M., \& Einstein, W.O. (1987). Leadership and outcomes of performance appraisal. Journal of Occupational Psychology, 60, 177-186.

56. Waldman, D.A., Bass, B.M., \& Yammarino, F.J. (1990). Adding to contingent reward behavior: The augmenting effect of charismatic leadership. Group and Organization Studies, 15(4), 381-394.

57. Williams, W. (2000). What makes a leader? Human Ecology, 28(3), 8-11.

58. Wofford, J.C., \& Goodwin, V.L. (1994). A cognitive interpretation of transactional and transformational leadership theories. Leadership Quarterly, 5(2), 161-186.

59. Wofford, J.C., Goodwin, V.L., \& Whittington, J.L. (1998). A field study of a cognitive approach to understanding transformational and transactional leadership. Leadership Quarterly, 9(1), 55-84.

60. Yammarino, F.J., Spangler, W.D., \& Bass, B.M. (1993). Transformational leadership and performance: A longitudinal investigation. Leadership Quarterly, 4(1), 81-102.

61. Zacharatos, A., Barling, J., \& Kelloway, E.K. (2000). Development and effects of transformational leadership in adolescents. Leadership Quarterly, 11(2), 211-227.

Notes 
